\title{
TAGHAYYUR AS A THEORETICAL BASIS OF MUSLIM AND NON-MUSLIM RELATIONS AT THE NAHDLATUL ULAMA'S BAHTHUL MASA'IL
}

Mohammad Rofiqul A'la, ${ }^{1}$ Rosihon Anwar, ${ }^{2}$ Nurwadjah Ahmad $^{3}$ and Dody S. Truna ${ }^{4}$

(1) Pesantren Ar-Risalah Bandung, Jawa Barat

${ }^{(2,3,4)}$ UIN Sunan Gunung Djati Bandung, Jawa Barat email: mohrofiqulala@gmail.comrosihonanwar@yahoo.co.id, nurwadjah.ahmad@gmail.com,dodystruna@uinsgd.ac.id

Abstract: This study discusses the history of fatwas on MuslimNon-Muslim relations issued by the Bahthul Masa'il Institute (LBM) of Nahdlatul Ulama from 1926 to 2019. This research is a type of qualitative research focused on studying LBM written materials. The perspective used is the Study of Religion with a theoretical analysis from Joachim Wach regarding the forms of expression of religious experience, especially in the sociological form. This study finds that, historically, NU issued fatwas by considering such sociological aspects that taghayyur (law change) method is used in law enforcement. By adhering to this principle, NU has formulated fatwas to maintain Muslimnon-Muslim relations under the umbrella of the Unitary State of the Republic of Indonesia. In this regard, NU argues that non-Muslims in Indonesia cannot be categorized in terms of the infidel in the nation-state because non-Muslim citizens in the nation-state context are not second-class citizens as contained in the concept of infidel with various types. The implication is the increasing quality of inter-religious relations that are increasingly harmonious in a plural society.

الملخص :تناقش هذه الدراسة تاريخ الفتاوى حول العلاقات بين المسلمين وغير المسلمين

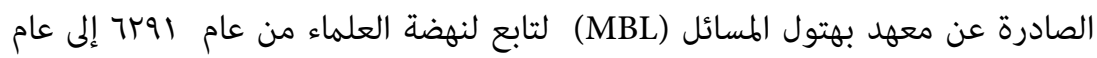

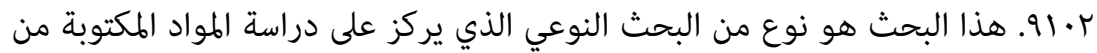


قبل MBL. المنظور المستخدم هو دراسة الدين مع تحليل نظري من hcaW mihcaoJ

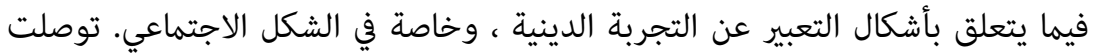

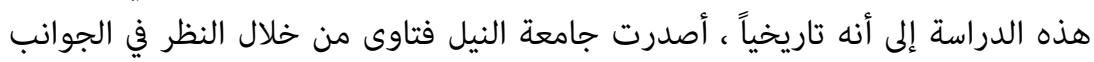

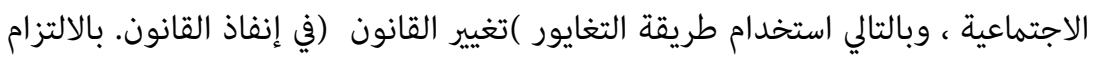
بهذا المبدأ ، قامت UN بصياغة فتاوى للحفاظ على العتلائل العاقات بين المسلمين وغير المسلمين

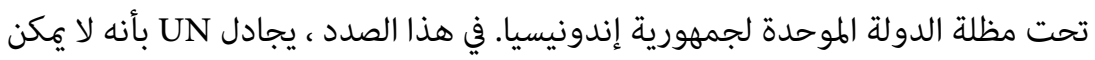

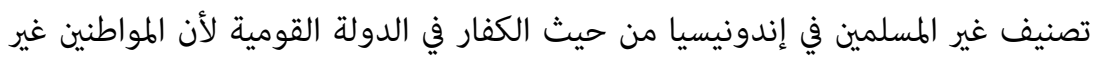

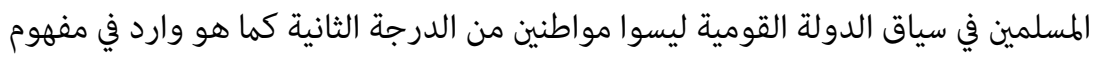

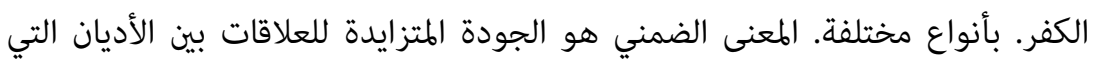
تزداد انسجامًا في مجتمع تعددي.

Abstrak: Penelitian ini membahas riwayat fatwa hubungan Muslim-Non-Muslim yang dikeluarkan oleh Lembaga Bahthul Masa'il (LBM) Nahdlatul Ulama dari tahun 1926 hingga 2019. Penelitian ini merupakan jenis penelitian kualitatif yang difokuskan untuk mengkaji bahan tertulis LBM. Perspektif yang digunakan adalah kajian agama dengan analisis teori dari Joachim Wach mengenai bentuk-bentuk ekspresi pengalaman beragama, terutama dalam bentuk sosiologis. Studi ini menemukan bahwa dalam sejarahnya, NU mengeluarkan fatwa dengan mempertimbangkan aspek sosiologis, sehingga memakai metode taghayyur (perubahan hukum) dalam penegakan hukum. Dengan berpegang pada prinsip ini, NU telah merumuskan fatwa-fatwa untuk menjaga hubungan Muslim-non-Muslim di bawah payung Negara Kesatuan Republik Indonesia. Dalam kaitan ini, NU berpendapat bahwa non-Muslim di Indonesia tidak dapat dikategorikan dalam istilah kafir dalam negarabangsa karena warga negara non-Muslim dalam konteks negarabangsa bukanlah warga kelas dua sebagaimana termuat dalam konsep kafir dengan berbagai jenisnya. Implikasinya adalah meningkatnya kualitas hubungan antar umat beragama yang semakin harmonis di masyarakat plural.

Keywords: fatwa, bahthul masail, taghayyur, muslin, non-muslim. 


\section{INTRODUCTION}

Indonesia is a country built on a plurality of tribes, cultures, and religions. ${ }^{1}$ The founders of this country view that pluralism is not an obstacle to realize unity and integrity. ${ }^{2}$ Pluralism is a blessing ${ }^{3}$ and wealth of the nation ${ }^{4}$ because it is the will of God (sunnatullah). ${ }^{5}$ However, some challenges and problems must be faced if we are to achieve this noble goal. These include strengthening the nation's ideology, national identity, diversity, economic development, and the like. ${ }^{6}$ One of the problems that is no less complicated in building the Indonesian state deals with the relationship between different religious adherents, diverse religious thought patterns, and the growth of schools of belief characteristics of Indonesian culture. ${ }^{7}$ From a sociological perspective, religion is an institution with a unifying function and social glue.

On the other hand, it can also be a divisive element if it is not appropriately managed. ${ }^{8}$ The problem becomes more complex when it is intertwined with economic inequality, differences in political perspectives, the weak rule of law, primordialism, ethnic sentiments, issues of equitable development, a crisis of elite models. The problems could contribute to the various conflicts occurred in society. Indonesia has recorded several religious conflicts either between two religions or among adherents of one religious community after the

1 Yohanes Parihala and Busro Busro, "Reclaiming Jesus as Source of Peace in Luke 12: 49-53 through the Perspective of Religious Pluralism in an Indonesian Context," HTS Teologiese Studies/Theological Studies 76, no. 4 (2020): 7.

2 M Yusuf Wibisono, "Sosiologi Agama" (Prodi P2 Studi Agama-Agama UIN Sunan Gunung Djati Bandung, 2020).

3 Eleonora Montuschi, "Pluralism: A Curse or a Blessing for Social Order?," 2011.

4 Peer Vries, "Does Wealth Entirely Depend on Inclusive Institutions and Pluralist Politics? A Review of Daron Acemoglu and James A. Robinson, Why Nations Fail," Ensayos de Economía 23, no. 43 (2013): 181-202.

5 Diana L Eck, "Is Our God Listening? Exclusivism, Inclusivism, and Pluralism," in Islam and Global Dialogue (Routledge, 2016), 41-70.

6 M Taufiq Rahman and Paelani Setia, "Pluralism in the Light of Islam," Jurnal Iman Dan Spiritualitas 1, no. 2 (2021), https://doi.org/http://dx.doi.org/10.15575/jis. v1i2.12269.

7 M. T. Rahman, "Pluralisme Politik," WAWASAN: Jurnal Ilmiah Agama Dan Sosial Budaya 34, no. 1 (2010): 1-13.

${ }^{8}$ Taufiq Rahman, "'Indianization' of Indonesia in an Historical Sketch," International Journal of Nusantara Islam 1, no. 2 (2013): 56-64. 
1998 reformation. For examples, such conflicts between MuslimsChristians since the Ambon conflict in January 1999 and conflicts between Shia-Sunni or Ahmadiyah followers. Sunni lasted from 2004 to 2012. ${ }^{9}$ In addition to the above disputes, Indonesia faces the threat of extremism, the strengthening of radicalism, and acts of terrorism. It can be observed from incidents of terror bombings at places of worship in various locations in Indonesia. Even when the Covid-19 pandemic is hitting the world and Indonesia has suffered the most from this pandemic attack, there are still terror events which lead to the destruction of places of worship..$^{10}$

Some other factors from religion can cause differences of opinion, disputes, and open conflict ranging from aspects of theology, ideology, understanding, and interpretation of sacred texts to the diversity of religious practices in the social life of religious communities. It is evidenced by the emergence of various schools of thought, sects, and religious organizations to congregations or congregations with smaller followers. Almost all major religions have such experiences. ${ }^{11}$

The labeling of "Muslim-infidel" which is seen as discriminatory has also become an actual theme in Indonesia. The debate over the term 'infidel' which is applied to adherents of religions other than Islam stems from the agenda held at the Alim Ulama National Conference and the NU Great Conference which started from Wednesday 27 February 2019 to 1 March 2019 at the Miftahul Huda Al-Azhar Islamic Boarding School at Banjar, West Java. This National conference has issued a decision that Non-Muslims in the nation-state context are citizens (muwatin) who have the same rights and obligations as other citizens. They do not fall into the 'infidel' types commonly found in classical fiqh books, namely Mu'ahad, Musta'man, Dhimmi, and Harbi. It is not necessarily analogous to non-Muslims in the context of the nation-state, especially in Indonesia.

Although istinbat (conclusion taking) in the NU LBM tradition does not dig directly from the original text (al-Qur'an and hadith), in practice, the arguments used in their decisions often include the

9 Rizka Diputra, "Lima Konflik SARA Paling Mengerikan Ini Pernah Terjadi Di Indonesia," Okezone.Com, 2016.

${ }^{10}$ Rio Rizky Pangestu, "Satu Pelaku Bom Di Gereja Katedral Makassar Diduga Perempuan," Pikiran Rakyat.Com, 2021.

${ }^{11}$ Abdurrahim Khathuf, Al-Khilaffi al-Fiqh wa al-'Aqidah, Dirasah fi Asbabihi wa Atsarihi wa Thuruqi Tahririhi (Beirut: Dar al-Kutub al-'Ilmiyah, 2018). 
text of the verses of the Qur'an or the hadiths that the jurists used as the argument for the legal product. The original text, of course, cannot be separated from interpretations that may differ in the hands of the commentators. Therefore, context analysis of socio-historical and environmental context of the performance of the original texts included in the results of the LBM-NU decision regarding the importance of Muslim-non-Muslim relations.

The North Sumatran Nahdlatul Ulama stated that they agreed with the recommendation of the term non-Muslim because they did not reach the status of infidels as in the book of Fiqh. ${ }^{12}$ Research says NU has never discussed issues regarding non-Muslim leadership, either at the Congress or the Alim Ulama National Conference, except regarding the election of non-Muslims as legislative councils. ${ }^{13} \mathrm{NU}$ gives a normative view that Muslims should not control their affairs to non-Muslims except in emergency conditions, including control as people's representatives. NU fatwas on the relationship between Muslims and non-Muslims can be classified into two typologies; fatwa on creed and fatwa on mu'amalah, with different characteristics. ${ }^{14}$ The fatwas of the NU Kiai related to issues categorized as ritual-aqidahtheological tend to be exclusive. NU's Bahthul Masa'il fatwas regarding $m u$ 'amalah are always inclusive. ${ }^{15}$ Another research shows that employing religious terminology such as "kafir" discriminates against other groups, both Muslim and non-Muslim. Radicalism can lead to intolerance and violence. ${ }^{16}$

This study focuses on the Nahdlatul Ulama (NU) mass organization's perspectives on Muslim-non-Muslim interactions, as

${ }^{12}$ Fitriani and Siti Aisyah, "Konsep Kafir Dalam Pandangan Nahdlatul Ulama (NU) Dan Forum Umat Islam (FUI) Sumatera Utara," Jurnal Studia Sosia Religia 2, no. 2 (2019).

${ }^{13}$ Izzul Madid, "Dinamika Pemikiran Nahdlatul Ulama Dalam Merespons Kepemimpinan Non Muslim Di Indonesia," Jurnal Ilmiah Mizani: Wacana Hukum, Ekonomi Dan Keagamaan 5, no. 2 (2018): 13-24, https://doi.org/10.29300/mzn. v6i1.2197.

${ }^{14}$ Luthfi Hadi Aminuddin, "RELASI MUSLIM DAN NON MUSLIM MENURUT NAHDLATUL ULAMA: Studi Atas Hasil-Hasil Keputusan Bahsul alMasa'il Nahdlatul Ulama," Justicia Islamica 11, no. 2 (2014).

${ }^{15}$ Abdul Wahid, "Persepsi 'Kafir' Pada Muslim Dan Non-Muslim: Konteks, Penggunaan, Dan Komunikasi Partisipatif," Tuturlogi: Journal of Southeast Asian Communication 1, no. 2 (2020): 79-92.

${ }^{16}$ Kunawi Basyir, "Menimbang Kembali Konsep Dan Gerakan Fundamentalisme Islam Di Indonesia," Al-Tahrir: Jurnal Pemikiran Islam 14, no. 1 (2014): 23-45. 
decided by the PBNU Executive Board via LBM-NU at the 2019 Nahdlatul Ulama National Conference. The fatwa's results are further examined. It covers Muslim-non-Muslim relations from 1926 until 2019. Therefore, this study will read and understand the PBNU fatwas on Muslim-non-Muslim relations, then dissect them again theoretically.

The object of this research is the LBM-NU fatwa documents relating to Muslim-non-Muslim relations in the decisions of the Congress, National Conference, and the Nahdlatul Ulama Great Conference between 1926-2019. This research type is document research that relies on data from written materials such as books, articles, and documents (archives). This document is external, namely, containing information produced by an institution and published to the mass media. ${ }^{17}$ Here, the documents regarding Muslim-non-Muslim relations in the decisions of the Congress, national conference, and the Nahdlatul Ulama Great Conference between 1926-2019 were analyzed critically. ${ }^{18}$ This context analysis deals with words, expressions, and sentences are used. Context defines text to different levels in different ways. Information about the contextual side is always identified with aspects that influence a decision so that the text and context are interrelated. ${ }^{19}$

Researchers describe or present research data, summarize or reduce data from various documents, ${ }^{20}$ including conducting a critical analysis of written documents to explore the content of various fatwa documents on Muslim and non-Muslim relations. This analysis process is carried out to obtain findings and recommendations accompanied by arguments for interpreting Muslim and non-Muslim

${ }^{17}$ Rosa Bologna, Franziska Trede, and Narelle Patton, "A Critical Imaginal Hermeneutics Approach to Explore Unconscious Infuences on Professional Practices: A Ricoeur and Jung Partnership," The Qualitative Report 25, no. 10 (2020): 34863518.

${ }^{18} \mathrm{P}$ Baxter and S Jack, "The Qualitative Report Qualitative Case Study Methodology: Study Design and Implementation for Novice Researchers," The Qualitative Report 13, no. 4 (2008): 544-59, https://doi.org/citeulike-articleid:6670384.

${ }^{19}$ Dody S. Truna, Pengantar Metode Riset: Buku Daras Untuk Mahasiswa (Bandung: Bandung Lembaga Penelitian UIN Sunan Gunung Djati, 2014).

${ }^{20}$ M. Mustari and M. T. Rahman, Pengantar Metode Penelitian (Yogyakarta: Laksbang Pressindo, 2012). 
relations according to Nahdlatul Ulama as outlined in the form of a fatwa document.

\section{CONCEPT OF KAFIR IN THE CONTEXT OF INTERRELIGIOUS RELATIONS IN INDONESIA}

The relationship between Muslims and non-Muslims is related to the terms of infidel for each party. The term of non-Muslim as a pronoun for infidels, meaning who do not embrace Islamic beliefs and teachings, or people who do not believe in Allah and His messengers; ${ }^{21}$ an offensive word used by some Muslims to refer to a person who is not a Muslim. ${ }^{22}$ In Islam, the term kafir relates to people who do not believe in Allah and the Prophet Muhammad, and the term kafir refers to those who do not practice Islam. For example, according to al-Zamakhshari and Tabatabai, infidels are enemies of Muslims, so it is impossible to become leaders of Muslims. In Wahbah al-Zuhaili's view, all the secrets of Muslims should not be known to them. ${ }^{23}$

In the history of Islam, this polemic between Muslims and nonMuslims initially surfaced in the reign of Umar bin Khattab as the second caliph after Abu Bakr al-Siddiq. At that time, Abu Musa alAsh'ari, as governor of Basra, appointed a Christian secretary. Umar bin Khattab, who later found out about it, asked him to replace it with a Muslim immediately. This incident caused a debate between the two parties which eventually gave birth to three camps, namely: (1) the camp that did not allow non-Muslims to hold positions; (2) the camp that declares the legitimacy of non-Muslims to become leaders in any position; (3) the camp that does not allow it to be a state official in the same class as the president, but if it is a vizier/minister whose authority is to obey the president (caliph), then it is allowed. ${ }^{24}$

In the context of Indonesia, the MUI organization discussed the concept of 'infidel'. It was determined at the 5th Ijtima Ulama of the

${ }^{21}$ KBBI, Kamus Besar Bahasa Indonesia (Republik Indonesia, Kementerian Pendidikan dan Kebudayaan, 2018).

${ }^{22}$ Press University Oxford, Oxford Learner's Dictionaries (United Kingdom: Oxford University Press, 2020).

${ }^{23}$ Mujar Ibnu Syarif, Presiden Non-Muslim Di Negara Muslim: Tinjauan Dari Perspektif Politik Islam Dan Relevansinya Dalam Konteks Indonesia (Pustaka Sinar Harapan, 2006).

${ }^{24}$ Wahid, “Persepsi 'Kafir' Pada Muslim Dan Non-Muslim: Konteks, Penggunaan, Dan Komunikasi Partisipatif." 
Indonesian Ulema Council (MUI) held in Tegal, Central Java, in 2015. The 5th Ijtima Ulama of the Indonesian Ulema Council (MUI) issued a fatwa about the law of disbelief criteria. The criteria for disbelief according to the MUI fatwa is,

A person who has taken the shahada (religion of Islam) applies to all Islamic laws. People who leave Islam (kafir) invalidate Islamic laws, including his marriage is automatically annulled, there is no custody for him against his child, there is no right to inherit and inherit, and if he dies in a state of $k u f r$, he is not buried in an Islamic cemetery and is cursed and will be far from Allah's mercy. ${ }^{25}$

Furthermore, MUI also has certain conditions before determining the verdict of disbelief, namely: a) Verification and validation must be carried out all matters related to i'tiqad, words, and actions that cause kufr, b) The verdict of an infidel is determined by heart, be careful as the last step after other efforts have been made, to prevent other Muslims from falling into similar kufr, c) Avoiding individualpersonal disbelief except after the establishment of a hujjah mu'tabarah (cogent reasoning), d) The verdict of disbelief can only be carried out collectively by competent scholars who understand the terms and barriers of takfir. ${ }^{26}$

\section{SHIFTING THE CONCEPT OF KAFIR TO NON-MUSLIMS}

The discussion of inter-religious relations in Bahthul Masáil requires such legal answers about the permissibility or inability to carry out an act in a particular case that it becomes a guide for NU citizens in determining attitudes and actions. However, the issue of interfaith relations was not the primary concern of the ulema when NU was founded. ${ }^{27}$ Nahdlatul Ulama (NU) has tried to respond to various religious nuanced events that can cause conflict in Indonesia. Therefore, a review of religious teachings is one of the discourses expected to

${ }^{25}$ Abdullah Muslich Rizal Maulana, Fauzan Adzima, and Muhammad Hudaya, "Konsep Kafir Dalam Tiga Agama Besar," Kalimah: Jurnal Studi Agama Dan Pemikiran Islam 18, no. 2 (2020): 157-83.

${ }^{26}$ Dwi Noviatin, "Konsep Pluralisme Agama: Suatu Kajian Komparatif Antara Jaringan Islam Liberal (JIL) Dan Majelis Ulama Indonesia (MUI)" (Universitas Islam Negeri Sultan Syarif Kasim Riau, 2013).

${ }^{27}$ Rumadi Ahmad, "Fatwa Hubungan Antaragama," R. Ahmad, Fatwa Hubungan Antaragama Di Indonesia, Kajian Kritis Tentang Karakteristik, Praktik, Dan Implikasinya, 2016, 2-3. 
reduce conflict, so there will be no assumption that religion is a barrier for humans to live together in a nation and state. ${ }^{28}$

From the first Congress in 1926 until the National Conference and Great Conference of NU 2018, 14 issues related to the relationship between Muslims and non-Muslims were discussed in LBM-NU. In the process, NU adheres to Aswaja (Ahl al-Sunnah wa al-Jama'ah) principles as the basis, ethical principles, attention, and care in building public relations with the background of pluralism of beliefs, religions, groups, and understandings among Muslims. The tenets of Aswaja that form the basis of the ethical principles of NU Kiai in formulating several legal decisions since, even before NU was formally founded, have become the hallmark and core of Aswaja teachings as carriers of mercy for the universe (rahmat li al- 'alamin). These principles are:29 1) al-tawassut (the middle way), 2) tawazun (balance and harmony), 3) al-tasamuh (tolerant), 4) ta'adul (just), 5) amar ma'ruf nahi munkar (calling to goodness and preventing evil).

These five principles show NU's concern for the importance of maintaining relations between Muslims and non-Muslims under the umbrella of the Unitary State of the Republic of Indonesia. NU views ukhuwwah islamiyah (Islamic brotherhood) and ukhuwwah wataniyah (national brotherhood) as worthy of careful attention and full of wisdom as two interrelated and complementary relationships patterns without contradicting each other ${ }^{30}$ Based on the stance formulated by the LTN of the PBNU (2011), it was emphasized that NU views the implementation of $u k h u w w a h$ as not only requiring uniformity but requiring a willingness to be "united in diversity." Therefore, ukhuwwah (brotherhood) in Islam (islamiyah), in nation (wataniyah), and in humanity (bashariyah) must be carried out in a proportional, balanced manner, without conflict with the Shari'ah. It confirms the pattern built by NU in the association of nation and state.

An example of the efforts of Nahdlatul Ulama (NU) in realizing unity to maintain the integrity of Indonesia's sovereignty is addressing the issue of "The Status of Non-Muslims in the Context of the Nation-

${ }^{28}$ Komaruddin Hidayat, Agama Punya Seribu Nyawa (Noura Books, 2012).

${ }^{29}$ Aminuddin, "RELASI MUSLIM DAN NON MUSLIM MENURUT NAHDLATUL ULAMA: Studi Atas Hasil-Hasil Keputusan Bahsul Al-Masa'il Nahdlatul Ulama."

${ }^{30}$ Aminuddin. 
State". This issue was raised at the National Conference of Alim Ulama. The NU Great Conference started from Wednesday, February 27, 2019, to March 1, 2019, at the Miftahul Huda Al-Azhar Islamic Boarding School, Banjar, West Java. The Alim Ulama National Conference took the theme "Strengthening Ukhuwah Wataniyah for People's Sovereignty." This National conference decided that NonMuslims in the Nation-State context were with the status of citizens (muwatin) who had rights and obligations that were equal to other citizens. They do not fall into infidel types commonly found in classical fiqh books, namely Mu'ahad, Musta'man, Dhimmi, and Harbi.

The infidel above cannot be compared to non-Muslims in the context of a nation-state. One of the most fundamental reasons is that non-Muslims, in the context of the nation-state, are not secondclass citizens unlike the various types of infidels above. This decision received support from various national figures for example, $\mathrm{KH}$. Ma'ruf Amin considered that the abolition of the call to infidels was aimed at maintaining the integrity of the Indonesian nation. ${ }^{31}$

In this context, many pieces of literature ${ }^{32}$ state that one of the prerequisites for realizing more harmonious intergroup relations is eliminating prejudice, intolerance, and hostility towards other groups. ${ }^{33}$ A tolerant and inclusive attitude in dealing with plurality must be seen as an integral indicator of noble character or character and a way to prevent acts of discrimination that can encourage intolerance and radicalism..$^{34}$ The plurality of the Indonesian nation is a reality that cannot be ignored and even must be accepted as wealth and potential. ${ }^{35}$

${ }^{31}$ Wahid, "Persepsi ‘Kafir’ Pada Muslim Dan Non-Muslim: Konteks, Penggunaan, Dan Komunikasi Partisipatif"; Muhamad Tisna Nugraha, "Fundamentalisme Pendidikan Agama Di Jejaring Sosial," Al-Tahrir: Jurnal Pemikiran Islam 18, no. 1 (2018): 41-62.

${ }^{32}$ Nancy H St. John and Ralph G Lewis, "Race and the Social Structure of the Elementary Classroom," Sociology of Education, 1975, 346-68; Walter G Stephan, "Improving Intergroup Relations in the Schools," School Desegregation in the 21st Century, 2002, 267-90.

${ }^{33}$ Gordon Willard Allport, Kenneth Clark, and Thomas Pettigrew, "The Nature of Prejudice," 1954.

${ }^{34}$ Maarif, Politik Identitas Dan Masa Depan Pluralisme Kita; Karwadi Karwadi, "Deradikalisasi Pemahaman Ajaran Islam," Al-Tahrir: Jurnal Pemikiran Islam 14, no. 1 (2014): 139-56.

${ }^{35}$ Rahman, "'Indianization' of Indonesia in an Historical Sketch.” 
Meanwhile, KH. Sahal Machfudl also stated that, theoretically, mu'amalah fiqh is related to solutions relevant to society's development and contemporary problems requiring religious answers. In this context, fiqh cases are not only asked for consideration on existing aqwal (opinions). Still, they are reformulated by considering social realities before the legal principles of maqashid al-shari'ah and maslahah 'ammah. ${ }^{36}$

\section{EXERCISING TAGHAYYUR THEORY}

As the socio-cultural development of society often appears, new symptoms or phenomena, events, and cases that give rise to responses, questions, and become challenges for the community related to laws according to religious teachings caused by the absence of legal fatwa regarding the case previously. ${ }^{37}$ According to YusufQardhawi, a fatwa explains Shari'a law in an issue as an answer to a question posed by a fatwa requester (mustafi) either individually or collectively. Fatwas are needed to stabilize increasingly complex social and cultural problems to minimize friction and people's diverse opinions so that all and usually only applies to certain areas. ${ }^{38}$ It is the thought that gave birth to the taghayyur theory. The essence of taghayyur idea is that the laws are not all fixed in Islam, but some rules can change. ${ }^{39}$ What remains is the sources of Islam law, namely the Qur'an and al-Hadith; ${ }^{40}$ while what has changed is the method of taking the law, namely there is ijma' (agreement of the scholars), and there is qiyas (analogous reasoning). ${ }^{41}$

The legal changes made by the Muslims after studying the text and reality are steps that show the dynamics of Islamic law. It is always

${ }^{36}$ KH.MASahalMachfudl,Agenda KrusialBahthulMasaa 'il: Mempertimbangkan Realitas Di Hadapan Kebenaran Teoretik, " in Khittah Dan Khidmah Nahdlatul Ulama, Ed. Oleh M. Bisri Abid Hattani, 1 Ed (Pati: Majma' Buhuts An-Nahdliyah, 2014).

${ }^{37}$ Muhammad Maulana Hamzah, "Peran Dan Pengaruh Fatwa MUI Dalam Arus Transformasi Sosial Budaya Di Indonesia,” Millah: Jurnal Studi Agama 1, no. 1 (2018): 127-54.

${ }^{38}$ Hamzah.

${ }^{39}$ Hammudah Abdal Ati, The Family Structure in Islam (University of Toronto Press, 1981).

${ }^{40}$ Bernard Weiss, "Interpretation Inlslamic Law: The Theory of Ijtihād," The American Journal of Comparative Law 26, no. 2 (1978): 199-212.

${ }^{41}$ Mohammad Hashim Kamali, "Law and Society: The Interplay of Revelation and Reason in the Shariah," The Oxford History of Islam, 1999, 107-53. 
relevant and can provide answers to the context of the times and in any hemisphere. It follows an axiom in Islamic legal theory, "The law changes according to the changing times and places (taghayyur al-ahkam bi taghayyur al-zaman wa al-makan)." It also applies to the dynamics of the fatwa on Muslim-non-Muslim relations in the discussion of NU's Bahthul Masail (discussing problems).

This theory of taghayyur can be traced from the development of social-social problems that affect the shift in the understanding of the concept of infidel and the summary of fatwas on interreligious relations in Muslim and non-Muslim relations. From the first NU congress in 1926 to the National Conference and the NU Great Conference in 2018, around 14 issues related to Muslim-non-Muslim relations have been discussed in the forum Bahthul Masail of NU. It shows NU's concern for the condition of relations between Muslims and nonMuslims under the umbrella of the Unitary State of the Republic of Indonesia. ${ }^{42}$

The problem of relations between Muslims and non-Muslims arose at the 4th Congress in 1929 in Semarang. The question is, "What is the opinion of the Congress about a Muslim working his land to an infidel with profit sharing and seeds from the cultivator (mukhabarah)?. Is zakat obligatory on the result when it reaches the nisab (the minimum limit of assets that must be subject to zakat)?"

Based on the Bahthul Masáil forum document, this question was the first interreligious relationship issue with Bahthul Masail at the NU Congress. This issue is not a question of whether or not it is permissible, but a legal case for Muslims who lease their land to infidels; Is the renter obliged to give zakat if the result reaches one nisab? ${ }^{43}$ Bahthul Masáil decides that a Muslim who rents out land is not obliged to pay zakat because zakat is obligatory on the seed owner. He is an infidel, and the obligation of zakat is required to be Muslim. The reference for this fatwa is as known in the books of Fiqh.

The problem of relations between Muslims and non-Muslims also appears in The 8th Congress in 1933 in Jakarta, namely, "If a

${ }^{42}$ Toto Suharto, "Indonesianisasi Islam: Penguatan Islam Moderat Dalam Lembaga Pendidikan Islam Di Indonesia," Al-Tahrir: Jurnal Pemikiran Islam 17, no. 1 (2017): 155-78.

${ }^{43}$ Rumadi Ahmad, Fatwa Hubungan Antaragama Di Indonesia (Gramedia Pustaka Utama, 2016). 
Muslim rents his house to a Magian, then the Magian puts his idol and worships it in that house. Is the rental legal? is the rent lawful or not?" The answer is: "The rental is valid, and the rent is lawful, with no difference of opinion among scholars. But when renting out understands or suspects that the polytheist (tenant) will worship idols in the house, then the law is haram, except for the opinion of Imam Hanafi. Likewise, selling oil that will be used to scent idols or live stock of sale to be known to be eaten without being slaughtered, based on a valid opinion that a disbeliever belongs to a group subject to sharia law well as Muslims.

The problem of relations between Muslims and non-Muslims appeared again at the 9th Congress in 1934 in Banyuwangi, East Java. The question posed is "how is it legal to study the books written by Christians, such as Munjid and others? Is it haram or not? What is the opinion of the Congress on Muslims who become Christians until they die and have not returned to Islam? Is it permissible to plant in Islamic graves or not?" The first question is about the law on studying the books written by Christians, such as al-Munjid. It is not permissible to review books written by non-Muslims, except for people who understand and distinguish between truth and falsehood. The fatwa referred to Mukhtashar al-Fawaid al-Meccan Surah, ${ }^{44}$ cited Alawi alSaqqaf mentioning the ban on reading Sirah al-Nakry because most of the vanity contents lie, so entirely haram because it is difficult to distinguish. Ibn Hajar al-Haytami in Tuhfat al-Muhtaj also noted that knowledge is not deep for people who can not afford it. It is forbidden to read books like the Torah that have been understood by duplicity and doubt. ${ }^{45}$

The second problem that emerged in the Congress- 9 is about a Muslim who converts to other religion and dies before returning to Islam. Based on the reference to the book Mirqah Shu'ud al-Tasdiqi, it is not permissible to bury apostates in Muslim cemeteries, because they leave the group of Muslims with their apostates." ${ }^{46}$

${ }^{44}$ Sayyid' Alwī Ahmad Al-Saqqaf, Hāsyiyah Tarsȳ̄h Al-Mustafidīn Bi Tausȳ̄h Fath Al-Mu'̄̄n (Mesir: Mustashfā al-Babī al-Halabī, 1955).

${ }^{45}$ Ahmad, Fatwa Hubungan Antaragama Di Indonesia.

${ }^{46}$ Muhammad Nawawi Al-Jawi, Marah Labid Tafsir Al-Nawawi, Juz 1 (Semarang: Toha Putera, 2014). 
The problem of relations between Muslims and non-Muslims also arose at the 12th Congress in 1937 in Malang, East Java. The question raised in the Congress is about a person who does not believe in the Day of Judgment and the commandments of Islam (kafir). The Congress attendants' answer to this question: the person is not recognized as a Muslim because he does not recognize the Prophet Muhammad as the messenger of Allah. This opinion is quoted from two books written by Zainuddin al-Malibari, Fath al-Mu'în, and Irshad al-'Ibâd. These two books explain that infidels who want to convert to Islam must be led to read "ashhadu" (I testify) because a person will not become a Muslim if there is no confession. In addition, infidels who want to convert to Islam are required to read two sentences of the creed. ${ }^{47} 48$

The issue of relations between Muslims and non-Muslims was also raised the following year, namely at the $13^{\text {th }}$ Congress in 1938 in Menes, Banten. The question presented is, "If a Muslim advises his son who is Muslim, saying: "You must remain in your religion." Likewise, his son is a Christian with the same words. Did the father become kufr with his words?" The answer to this question: "if there is no meaning in what he said, pleased with the child is the child's Christianity, then it does not become kufr. But if he is deliberately pleased with his child's Christianity, then he becomes kufr and is separated from the religion of Islam." This opinion is based on the book Bughyah al-Mustaryidin written by Badurrahman Ba'alawi. The part that is referred to is a text which means that if a Muslim comes out of words that disbelieve, while he does not know the meaning or knows the purpose, but some indications show his unwillingness or doubt, then he does not become an infidel. ${ }^{49}$

The problem of relations between Muslims and non-Muslims arose at the 14th Congress in 1939 in Magelang, Central Java. The issue raised at that time: "Which book of Samawiyah must be believed from the Torah, the Bible, and the Zabur? What are the books among Christians, Catholics, and Jews today? because they have changed some of the sentences." The answer is that these books are not

${ }^{47}$ Ahmad, "Fatwa Hubungan Antaragama."

${ }^{48}$ Zainuddin bin Abdul Aziz al-Malibari, Fath Al-Mu'in, terj, Abul Hiyadh (Surabaya: Al-Hidayah, 1993).

49 Abdurrahman bin Muhammad Ba'Alawi, Bughyah Al-Mustarsyidin (Beirut: Dar Al-Fikr, 1997). 
Samawiyah books that must be believed in. This opinion is based on the book Izhar al-Haq written by Rahmatullah Khalilurrahman alHindi. By quoting Imam al-Qurtubi, Rahmatullah said that the holy book in the hands of Christians (the Bible) is not the Bible as meant by the word of God, which was conveyed through the Prophet in the QS. Ali Imran 3-4 and the Torah in the hands of the Jews are not the Torah referred to in verse because it already contains deviations. ${ }^{50}$

The problem of relations between Muslims and non-Muslims arose at the 16th Congress in 1946 in Purwokerto, Central Java. The question is, "How is it legal for Muslims to jo in associations that are not based on Islam? Is it permissible or not? If not, then what is the attitude of PBNU towards the members in the association?" The answer to this problem gave birth to a fatwa that Muslims who join associations or parties that are not based on Islam, which is interpreted that: (1) If it harms Islam, then it is Haram; (2) If it benefits Islam then Good; (3) If it does not harm and does not benefit Islam then it is ok (Jaiz). This fatwa is based on the reference to the Qurrah al-'Ain li Sharh Waraqat, namely. ${ }^{51}$

The issue of relations between Muslims and non-Muslims was also on the agenda for discussion at the 1960 National Conference and the 1st PBNU Greater Conference in Jakarta. The issue raised is regarding the law on the permissibility of a Muslim man to marry an infidel woman. The answer to these problems resulted in a fatwa: it is not allowed or forbidden and it is unlawful to marry a Muslim man if the woman is not kitabi infidels, the pure descendants of the original (parent) who entered into the religion before in naskh (change) with the apostolate Prophet Muhammad, such as apostate women, Magi, Watsani, Kitabi infidels whose parents converted to that religion after being mansukh (changed) like the children of our nation's daughters, Indonesia. This fatwa is based on a reference from the book Tuhfah al-Tullab bi Sharh al-Tahrir and Hashiyah al-Sharqawi.

The problem of relations between Muslims and non-Muslims also arose at the 26th Congress in 1979 in Semarang. The question

${ }^{50}$ Ahmad, Fatwa Hubungan Antaragama Di Indonesia; Muhammad Rahmatullah Al-Kairanawî and Ahmad Hijazi al-Saqqa', "Izhar Al-Haq," Muhammad Ahmad Muhammad Abd Al-Qadir Khalil Malkawi (Pnyt.). Jil 1, no. 2 (2001): 3.

${ }^{51}$ Abdul Karim bin Hawazin Qusyairi, "Lataif Al-Isyarat," Haiah Al-Misriyyah Al-A'mmah Lil Kitab, 1981. 
raised regarding this issue is "What is the ruling on the translation/ interpretation of the Qur'an in a foreign language by people who are not Muslim or Muslims who translate it into Indonesian and foreign languages?" The answer from Bahthul Masail is in the fatwa formulation that: Translations or interpretations of the Qur'an made by people who are not Muslim are highly doubtful. Therefore, it is forbidden to read and quote from such translations/interpretations.

The issue of relations between Muslims and non-Muslims was also discussed at the 28th Congress in 1989 in Krapyak, Yogyakarta. The theme discussed is the law of marriage between two people of different religions in Indonesia. This problem resulted in a fatwa that the marriage law was invalid as decided in the 1962 NU Congress and the 1968 Tariqah Mu'tabarah Conference. Imam Shafi'i explains the details of this law in the book Mukhtashar al-Muzani. "A Muslim woman is not lawful for a non-Muslim man, whether the woman is free or a slave with the agreement of the scholars. At the same time, apostate women are not lawful for anyone. It is not lawful for a Muslim man because he is a non-Muslim woman who is not allowed (such as a genuine non-Muslim), and it is not lawful for a non-Muslim man because there is still an Islamic relationship with him." ${ }^{52}$

The problem of Muslim and non-Muslim relations that became the agenda of discussion Bahthul Masail's 30th at the Congress in 1999 in Lirboyo, Kediri, East Java, was related to the existence of crises, whether related to the monetary crisis, a crisis of trust, or crisis of faith, which hit the Indonesian nation at that time. The crisis, in turn, demanded the Indonesian people to increase their unity and integrity and avoid the threat of disintegration caused by the crisis. Among the efforts made by this nation is the holding of joint prayers between various religious communities (Islam, Catholicism, Christianity, Hinduism, and Buddhism). The issue raised is related to communal prayer between various religious communities, which is often carried out in Indonesia. The second issue that is also the subject of discussion is the limits of inter-religious cooperation allowed by Islamic law.

The answer of the Bahthul Masail forum to the first problem: it is not permissible to hold joint prayers unless the method and content do not conflict with Islamic shari' ah. This fatwa is based on the reference

\footnotetext{
${ }^{52}$ Abu Ishaq Ibrahim al-Syairazi, Muhazzab fi Fiqh al-Imam al-Syafi'i, Juz I, (Beirut: Dar Al-Fikr, 1988).
} 
to the Book of Futuhat al-Wahhab bi Taudhih Fath al-Wahhab, Muslims must prevent non-Muslims from showing evil in front of us, such as listening to their words to us: "Allah is one of the three Gods."

The problem of relations between Muslims and non-Muslims arose at the 30th Congress in 1999 in Lirboyo, Kediri, East Java was about Muslims controlling state affairs to non-Muslims. The fatwa issued on this issue states that Muslims are not allowed to delegate state affairs to non-Muslims except in an emergency. This fatwa is based on the opinion of the scholars, asking for help from infidels is not allowed even in an emergency. However, Abu Sa'id al-Mutawalli, in his book al-Tatimmah clearly explains the permissibility of asking for help from non-Muslims in an emergency." 53

At the National Conference of Alim Ulama and NU Great Conference, held in 2006 at the Sukolilo Haji Dormitory of Surabaya, some issues on Muslim and non-Muslim relations were raised especially on religious life in a heterogeneous society. In these circumstances, the attitude of tasamuh (tolerance) between religious communities becomes a necessity. Islam respects the values of tolerance towards followers of other religions within the corridor s and limits that have been determined. The question raised is, "How is it legal for a Muslim to inaugurate a place of worship for another religion?'The fatwa of Bahthul Masail regarding this issue is that opening a place of worship for another religion is haram. The fatwa refers to the Ahkam al-Qur'an, namely, "And the Word of Allah Swt.: "And do not help in committing sins and transgressions." is a prohibition on helping people other than us (Muslims) in doing disobedience to Allah Swt." 54

With the taghayyur method in responding to the pattern of relations between Muslims and non-Muslims, it appears that NU, as the most prominent Islamic organization in Indonesia, has shown a sociological expression in religion. It follows the Sociological theory of religion from Joachim Wach. Wach considers that religion has theoretical, practical, and sociological expressions. ${ }^{55}$ In terms of sociological

${ }^{53}$ Syekh Muhammad Abdul Aziz al-Khalidi, "Hawasyi al-Syarwani wa Ibn Qasin al-'Ibadi 'ala Tuhfah al-Muhtaj bi Syarh al-Minhaj, Juz 8 ( Beirut: Dâr al-Kutub alIlmiyah, 1996).

${ }^{54}$ Al Jassas, “Imam Abu Bakar Ahmad Bin Ali, Al Razi.(1928),” Ahkamul Quran, n.d.

${ }^{55}$ Joachim Wach, The Comparative Study of Religions (Columbia: University Press, 2016). 
expression, Wach stated that religious expressions related to religious social organizations, apart from group and leadership forms, are: What is the relationship between religion and other societies? ${ }^{56}$ Here NU has carried out the sociological expression marked by the doctrine that legitimizes it, namely the fatwas issued by the NU's Bahtsul Masail institution. It is also recognized by Muhammadiyah, the secondlargest Islamic organization in Indonesia. ${ }^{57}$ Thus, with its fatwas on Muslim and non-Muslim relations, NU has contributed greatly to the unity of the Republic of Indonesia.

\section{CONCLUSION}

NU had issued fatwas regarding the concept of 'kafir' and the position of non-Muslim citizens even before the 2019 National Deliberation. The themes concerned the form of the state, the relationship between Islam and the state, the rights of non-Muslim minorities in state politics at almost all levels, including daily affairs such as land rental to matters relating to the state. The dynamics of legal fatwas issued by LBM NU consider various aspects, ranging from the methodological aspects of law enforcement, the relationship between religion and the state, the relationship between religious organizations and the government, to the concepts and perceptions of the ulama regarding the position of religions other than Islam. NU holds the theory of Islamic law taghayyur (legal change), namely that the law circulates with illat (reasons). With this theory, NU concludes that infidels in the Indonesian context must use the term 'non-Muslim' because it raises the spirit of egalitarianism embraced by the Indonesian people.

\section{REFERENCES}

Ahmad, Rumadi. Fatwa Hubungan Antaragama Di Indonesia, Kajian Kritis Tentang Karakteristik, Praktik, Dan Implikasinya, 2016, 2-3.

- Fatwa Hubungan Antaragama Di Indonesia. Gramedia Pustaka Utama, 2016.

\footnotetext{
${ }^{56}$ Joachim Wach, Sociology of Religion, vol. 16 (Routledge, 2019).

${ }^{57}$ Maarif, Politik Identitas Dan Masa Depan Pluralisme Kita.
} 
Al-Jawi, Muhammad Nawawi. Marah Labid Tafsir Al-Nawawi. Juz 1, Semarang: Toha Putera, 2014.

Al-Kairanawî, Muhammad Rahmatullah, and Ahmad Hijazi alSaqqa'. Jilid 1, Izhar Al-Haq. Muhammad Ahmad Muhammad Abd Al-Qadir Khalil Malkawi (Pnyt.). 2001.

al-Khalidi, Syekh Muhammad Abdul Aziz. Hawasyi al-Syarwani wa Ibn Qasin al-'Ibadi 'ala Tuhfah al-Muhtaj bi Syarh al-Minhaj. Juz 8, Beirut: Dâr Al-Kutub Al-Ilmiyah, 1996.

Al-Malibari, Zainuddin bin Abdul Aziz. Fath Al-Mu'in, trej. Abul Hiyadh, Surabaya: Al-Hidayah, 1993.

Al-Saqqaf, Sayyid' Alwī Ahmad. Hāsyiyah Tarsȳ̄h al-Mustafidīn bi Tausȳ̄h Fath Al-Mu'īn. Mesir: Mustashfā al-Babī al-Halabī, 1955.

Al-Syairazi, Abu Ishaq Ibrahim Al. Muhazzab fi Fiqh fl-Imam flSyafi'i. Juz 1, Beirut: Dar Al-Fikr, 1988.

Allport, Gordon Willard, Kenneth Clark, and Thomas Pettigrew. The Nature of Prejudice, 1954.

Aminuddin, Luthfi Hadi. "RELASI MUSLIM DAN NON MUSLIM MENURUT NAHDLATUL ULAMA: Studi Atas Hasil-Hasil Keputusan Bahsul Al-Masa'il Nahdlatul Ulama." Justicia Islamica 11, no. 2 (2014).

Ati, Hammudah Abdal. The Family Structure in Islam. University of Toronto Press, 1981.

Ba'Alawi, Abdurrahman bin Muhammad. Bughyah al-Mustarsyidin. Beirut: Dar al-Fikr, 1997.

Basyir, Kunawi. "Menimbang Kembali Konsep Dan Gerakan Fundamentalisme Islam Di Indonesia." Al-Tahrir: Jurnal Pemikiran Islam 14, no. 1 (2014): 23-45.

Baxter, P, and S Jack. "The Qualitative Report Qualitative Case Study Methodology: Study Design and Implementation for Novice Researchers." The Qualitative Report 13, no. 4 (2008): 544-59. https://doi.org/citeulike-article-id:6670384. 
Bologna, Rosa, Franziska Trede, and Narelle Patton. "A Critical Imaginal Hermeneutics Approach to Explore Unconscious Infuences on Professional Practices: A Ricoeur and Jung Partnership." The Qualitative Report 25, no. 10 (2020): 34863518 .

Diputra, Rizka. "Lima Konflik SARA Paling Mengerikan Ini Pernah Terjadi Di Indonesia.” Okezone.Com, 2016.

Eck, Diana L. "Is Our God Listening? Exclusivism, Inclusivism, and Pluralism.” In Islam and Global Dialogue, Routledge, 2016.

Fitriani, and Siti Aisyah. "Konsep Kafir Dalam Pandangan Nahdlatul Ulama (NU) Dan Forum Umat Islam (FUI) Sumatera Utara." Jurnal Studia Sosia Religia 2, no. 2 (2019).

Hamzah, Muhammad Maulana. "Peran Dan Pengaruh Fatwa MUI Dalam Arus Transformasi Sosial Budaya Di Indonesia." Millah: Jurnal Studi Agama 1, no. 1 (2018): 127-54.

Hidayat, Komaruddin. Agama Punya Seribu Nyawa. Noura Books, 2012.

Jassas, Al. "Imam Abu Bakar Ahmad Bin Ali, Al Razi.(1928)." Ahkamul Quran, n.d.

John, Nancy H St., and Ralph G Lewis. "Race and the Social Structure of the Elementary Classroom." Sociology of Education, 1975, 346-68.

Kamali, Mohammad Hashim. "Law and Society: The Interplay of Revelation and Reason in the Shariah." The Oxford History of Islam, 1999, 107-53.

Karwadi, Karwadi. "Deradikalisasi Pemahaman Ajaran Islam.” AlTahrir: Jurnal Pemikiran Islam 14, no. 1 (2014): 139-56.

KBBI. Kamus Besar Bahasa Indonesia. Republik Indonesia, Kementerian Pendidikan dan Kebudayaan, 2018.

Khathuf, Abdurrahim. Al-Khilaffi al-Fiqhi wa al-'Aqidah, Dirasah fi Asbabihi wa Atsarihi wa Thuruqi Tahririhi. Beirut: Dar alKutub al-'Ilmiyah, 2018. 
Maarif, Ahmad Syafii. Politik Identitas Dan Masa Depan Pluralisme Kita. Pusat Studi Agama dan Demokrasi (PUSAD), Yayasan Wakaf Paramadina, 2010.

Machfudl, KH. Sahal. Agenda Krusial Bahtsul Masaa'il: Mempertimbangkan Realitas Di Hadapan Kebenaran Teoretik," in Khittah Dan Khidmah Nahdlatul Ulama, Ed. Oleh M. Bisri Abid Hattani, 1 Ed. Pati: Majma' Buhuts An-Nahdliyah, 2014.

Madid, Izzul. "Dinamika Pemikiran Nahdlatul Ulama Dalam Merespons Kepemimpinan Non Muslim Di Indonesia.” Jurnal Ilmiah Mizani: Wacana Hukum, Ekonomi Dan Keagamaan 5, no. 2 (2018): 13-24. https://doi.org/10.29300/mzn.v6i1.2197.

Maulana, Abdullah Muslich Rizal, Fauzan Adzima, and Muhammad Hudaya. "Konsep Kafir Dalam Tiga Agama Besar." Kalimah: Jurnal Studi Agama Dan Pemikiran Islam 18, no. 2 (2020): 157-83.

Montuschi, Eleonora. "Pluralism: A Curse or a Blessing for Social Order?," 2011.

Mustari, M., and M. T. Rahman. Pengantar Metode Penelitian. Yogyakarta: Laksbang Pressindo, 2012.

Noviatin, Dwi. "Konsep Pluralisme Agama: Suatu Kajian Komparatif Antara Jaringan Islam Liberal (JIL) Dan Majelis Ulama Indonesia (MUI)." Universitas Islam Negeri Sultan Syarif Kasim Riau, 2013.

Nugraha, Muhamad Tisna. "Fundamentalisme Pendidikan Agama Di Jejaring Sosial." Al-Tahrir: Jurnal Pemikiran Islam 18, no. 1 (2018): 41-62.

Oxford, Press University. Oxford Learner's Dictionaries. United Kingdom: Oxford University Press, 2020.

Pangestu, Rio Rizky. “Satu Pelaku Bom Di Gereja Katedral Makassar Diduga Perempuan.” Pikiran Rakyat.Com, 2021.

Parihala, Yohanes, and Busro Busro. "Reclaiming Jesus as Source of Peace in Luke 12: 49-53 through the Perspective of Religious Pluralism in an Indonesian Context." HTS Teologiese Studies/ Theological Studies 76, no. 4 (2020): 7. 
Qusyairi, Abdul Karim bin Hawazin. "Lataif Al-Isyarat." Haiah AlMisriyyah Al-A'mmah li al-Kitab, 1981.

Rahman, M. T. "Pluralisme Politik." WAWASAN: Jurnal Ilmiah Agama Dan Sosial Budaya 34, no. 1 (2010): 1-13.

Rahman, M Taufiq, and Paelani Setia. "Pluralism in the Light of Islam." Jurnal Iman Dan Spiritualitas 1, no. 2 (2021). https:// doi.org/http://dx.doi.org/10.15575/jis.v1i2.12269.

Rahman, Taufiq. "'Indianization'of Indonesia in an Historical Sketch." International Journal of Nusantara Islam 1, no. 2 (2013): 56-64.

Stephan, Walter G. "Improving Intergroup Relations in the Schools." School Desegregation in the 21st Century, 2002, 267-90.

Suharto, Toto. "Indonesianisasi Islam: Penguatan Islam Moderat Dalam Lembaga Pendidikan Islam Di Indonesia." Al-Tahrir: Jurnal Pemikiran Islam 17, no. 1 (2017): 155-78.

Syarif, Mujar Ibnu. Presiden Non-Muslim Di Negara Muslim: Tinjauan Dari Perspektif Politik Islam Dan Relevansinya Dalam Konteks Indonesia. Pustaka Sinar Harapan, 2006.

Truna, Dody S. Pengantar Metode Riset: Buku Daras Untuk Mahasiswa. Bandung: Bandung Lembaga Penelitian UIN Sunan Gunung Djati, 2014.

Vries, Peer. "Does Wealth Entirely Depend on Inclusive Institutions and Pluralist Politics? A Review of Daron Acemoglu and James A. Robinson, Why Nations Fail." Ensayos de Economía 23, no. 43 (2013): 181-202.

Wach, Joachim. Sociology of Religion. Vol. 16. Routledge, 2019.

- The Comparative Study of Religions. Columbia University Press (1958), 2016.

Wahid, Abdul. "Persepsi 'Kafir' Pada Muslim Dan Non-Muslim: Konteks, Penggunaan, Dan Komunikasi Partisipatif." Tuturlogi: Journal of Southeast Asian Communication 1, no. 2 (2020): 7992. 
Weiss, Bernard. "Interpretation Inlslamic Law: The Theory of Ijtihād." The American Journal of Comparative Law 26, no. 2 (1978): 199-212.

Wibisono, M Yusuf. "Sosiologi Agama." Prodi P2 Studi AgamaAgama UIN Sunan Gunung Djati Bandung, 2020. 
